\title{
Observations on EXCOM's 60th Session (2009): Does UNHCR Need (More) EXCOM Conclusions?
}

\author{
Michael Barutciski
}

\section{Introduction}

Despite the lack of academic interest in the work of the Executive Committee of the Program of the UN High Commissioner for Refugees (EXCOM), there is arguably no forum that is more important in terms of international refugee protection than the annual EXCOM sessions. This is the public face of diplomatic efforts to promote international refugee protection. What goes on behind closed doors in EXCOM's Standing Committee may be more revealing in terms of the policy developments envisaged by influential states, but it cannot replace public declarations made by state representatives at the EXCOM sessions.

While there is a risk that its plenary sessions will be bogged down and become overly politicized, EXCOM should attract the attention of analysts concerned by refugee problems around the world. Indeed, UNHCR should be encouraged to make publicly accessible on its website the various state declarations so that we better understand the positions defended by our governments on the international stage.

The EXCOM session held in October 2009 was the 60th session held since the body was created fifty years earlier. The discussions in this important forum have evolved over the decades as new expressions have emerged that reflect Western intellectual trends: "human security," "delivering protection," "humanitarian space" (to be distinguished from "protection space"), etc. Yet refugee protection problems remain fundamentally similar to those preoccupying the governments that first created the post of High Commissioner for Refugees in 1921. For the most part, the formal questions associated with the origins of international refugee protection remain valid almost nine decades after they were being formulated in the early phases of the multilateral system created after the First World War. What obligations will states accept towards fleeing foreigners designated as "refugees"? What forms of international solidarity will states accept in order to help other states directly affected by refugee flows?

As UNHCR's governing body, EXCOM has to deal with the same difficult problem of fleeing refugees in a world of sovereign states that jealously guard their territorial sovereignty. Yet it also has to deal with the growing number of influential non-state actors in a new context in which it is no longer controversial to suggest that state sovereignty is not absolute. International refugee law, along with human rights law, has developed considerably since the first attempts to create international institutional structures during the first half of the twentieth century.

\section{EXCOM and Its Structural Ambiguities}

It is worth emphasizing that UNHCR, as a subsidiary organ of the UN General Assembly, is supposed to collaborate with governments which represent states. The first paragraph of UNHCR's 1950 Statute specifies that it "shall assume the function of providing international protection [for refugees] ... and of seeking permanent solutions ... by assisting Governments and, subject to the approval of the Governments concerned, private organizations to facilitate the voluntary repatriation ... or their assimilation" (emphasis added).

The difficulties of international protection are illustrated by the fact that UNHCR is supposed to protect refugees in collaboration with UN members which are often reluctant host states. The requirement to co-operate with governments is also found explicitly and implicitly throughout paragraph 8 of the Statute that outlines the activities of UNHCR. This fundamental aspect of its mandate follows the traditional role of the High Commissioner as articulated in the 1920s. ${ }^{1}$ There is a tension between two potentially contradictory functions: applying pressure on states to protect refugees and collaborating with governments. There are clearly limits to the pressure UNHCR can apply 
without indisposing the states that created it and thereby jeopardizing its future. ${ }^{2}$ Watchdog-type roles or activities advocated by some (particularly Western) jurists who place their trust in mechanisms "untainted by the political control of states"3 run counter to the logic of a system set up by states.

With its connection to a ninety-year institutional history, UNHCR has nevertheless acquired considerable authority in international law and should not be criticized lightly. However, it may be worth pointing out some basic confusion or misunderstanding about general aspects of the mandate.

During the last few years, some comments by UNHCR's most senior lawyers may be interpreted as suggesting UNHCR is an independent agency. The Director of International Protection has noted that "[t]here is the perennial issue in some quarters of a perceived lack of independence because UNHCR's budget hinges largely on the voluntary contributions of donor countries." Similarly, the Assistant High Commissioner (Protection) has described UNHCR as "a humanitarian agency which operates independently of any political agenda ... [working] in accordance with basic principles of humanitarian actionnotably impartiality and independence." ${ }^{5}$

Whereas the above statements are not unequivocal, the European Court of Human Rights has clearly described UNHCR as a body "whose independence, reliability and objectivity are, in [the court's] view, beyond doubt." 6 Yet nothing in the Statute suggests UNHCR was intended to operate as an independent agency. On the contrary, the reference to independence that was mentioned in the initial 1949 resolution calling for the creation of UNHCR was not included later in the subsequent 1950 resolution and Statute that actually created the agency. ${ }^{7}$ Again, this echoes a basic issue that was considered carefully by the members of the League of Nations in the 1920s and 1930s. ${ }^{8}$

Even if we acknowledge that UNHCR is formally "dependent," decades of practice may have reinforced a de facto autonomy in the sense that credibility on protection requires that UNHCR not be perceived as a simple tool to be manipulated by states. Although it is relatively clear that many within UNHCR believe the agency's authority would suffer if it were to be perceived as lacking in independence, some of its actions, such as its long-standing efforts to initiate the process for the adoption of EXCOM conclusions, suggest that it has in fact exercised a certain amount of autonomy over the years.

It is also worth remembering that EXCOM was originally intended to advise the High Commissioner, not states. ${ }^{9}$ While it is not clear that the mandate was to advise on protection (i.e. sensitive) matters, in practice EXCOM began addressing protection approximately three years after its creation. ${ }^{10}$ A decade later it was directly advising states on protection problems. ${ }^{11}$

These developments occurred with the encouragement of the predecessors to the currently named Division of International Protection (DIP) which drafted and pushed for progressive conclusions on protection. ${ }^{12}$ This situation eventually resulted in an ever-increasing number of EXCOM conclusions that were largely intended to defend previously adopted norms, rather than to respond to requests for guidance from the High Commissioner or states.

While it is understandable that an international cadre of UN specialists has developed unparalleled expertise in refugee protection, there are risks in having UNHCR assume the responsibilities that were reserved for states. ${ }^{13}$ Perhaps the most striking example of the problems that arise from this institutional phenomenon is the aborted conference in early 1977 that convened under UNHCR's leadership in order to adopt a treaty on asylum. Indeed, a DIP-centred policy-making process runs the risk of complete failure in an international system that is ultimately based on voluntary state involvement. ${ }^{14}$

We may ask ourselves whether EXCOM has acted ultra vires or whether these important aspects of its practical evolution have been validated by the de facto acquiescence of member states. It could be argued that the legal maxim boni judicis est ampliare jurisdictionem justifies an enlargement of competence within tolerable limits. ${ }^{15}$ The point being raised here is that an EXCOM under too much influence from UNHCR's protection specialists finds itself possibly exceeding the threshold limit. Contrary to the advice of some observers, it is unlikely that the solution to this complicated problem will be to recognize a de facto practice by providing EXCOM with a formal mandate to advise states on protection. ${ }^{16}$

As a governing body of UNHCR, EXCOM has to deal with various internal divisions from the perspective of states. Recent EXCOM sessions reveal that various participants have diverging views on such contentious issues as the institution's rapid expansion, the potential tension between protection and assistance, an asylum-centred focus as opposed to a comprehensive strategy, an activist as opposed to a conservative state-focused approach, etc.

\section{Context of 60th Session and Governmental Delegations}

There are various ways to interpret the appropriate role for UNHCR and its EXCOM, just as there are different approaches to ensure effective refugee protection. The pessimistic tone of recent Notes on International Protection prepared for EXCOM by UNHCR's Division of International Protection, as well as the harsh assessment of NGOs at 
the 60th session, suggests that new thinking is needed to improve the situation of the world's refugees.

The increasingly interdisciplinary nature of forced migration studies has resulted in many new analytical insights that would have been difficult to imagine in the past. However, interdisciplinary research also carries some risks, and unfortunately a certain amount of confusion has been created in relation to the normative framework. One of the results is that many non-legal analysts do not seem to understand fully that treaties (sometimes called "conventions," "protocols," etc.) are adopted voluntarily by states and cannot be imposed by other international actors (e.g. international organizations, NGOs).

To the extent that understandings of our modern international system are still based on a positivist perspective that clearly distinguishes between legal rules and moral or political duties, it is important to appreciate that states have to willingly give up their sovereignty on issues that are to be regulated by treaties. In this context, it should be underlined that it was difficult enough to get states to accept nonrefoulement in a treaty signed in 1951 (with ambiguities still remaining as to its interpretation), while the idea of a legally binding right to asylum did not materialize in 1951 and was also rejected at the international conference on the subject held in 1977.

Yet confusion relating to normative relativity is not solely the result of terminological or conceptual gaps between academic disciplines. This becomes apparent when UNHCR documents mention vaguely a "right to asylum" or when senior UNHCR legal specialists suggest there is a "collective duty" to help struggling host states in terms of burden-sharing. While most lawyers will be aware (and will acknowledge) that the terms "right" or "duty" are used here in a non-legal manner, social scientists and other non-legal analysts may be left with the impression that we are dealing with binding legal norms. This kind of misleading use of terms is common in forced migration studies, and it points to questionable interdisciplinary practices.

Although it goes against the flow of conventional thinking in the field, it may sometimes be more effective to be blunt and upfront in our descriptive analysis and assessment of the status quo when we want to encourage reform. For example, there is no legal obligation to share the refugee burden in any of the treaties that make up international refugee law. If we want reform, let us acknowledge this unfortunate situation, and try to build realistically rather than bluff our way forward by pressuring certain vulnerable states to accept refugees in the name of solidarity.

Before suggesting there is a conflict between principles and practical realities, ${ }^{17}$ it is prudent to make sure an accurate picture of state obligations is presented, including acknowledgement of problems related to normative relativity and/or disputes over interpretation of norms. If refugee advocates invoke legal authority to uphold refugee protection principles, then they should strive to present interpretations of international law that are likely to achieve consensus. Otherwise, so-called principled approaches will risk being dismissed and the strategy will backfire. The resulting potential for marginalization of the law will not further the cause of refugee protection in the long run.

It follows from the above comments that a realistic and reform-minded EXCOM should be the forum for genuine discussions that take into account state commitments and objections in an honest and upfront manner.

Indeed, underestimating the importance of state sovereignty has arguably led to several High Commissioners overshooting on prominent issues in recent decades: the mistaken supposition that the so-called "Convention Plus initiative" launched in 2002 could lead to a new complementary treaty on burden-sharing, ${ }^{18}$ as well as the ill-prepared push in 1977 for a treaty that would establish a right to asylum. ${ }^{19}$ Neither of these prominent initiatives succeeded, and some observers consider them as significant diplomatic defeats.

The state delegations that arrive at Geneva for the EXCOM sessions in order to present national views and to negotiate common positions can be complex in the sense that they are often composed of representatives from different ministries and departments that may have divergent interests. ${ }^{20}$ As such, a state's consensus declaration can carry considerable weight as a compromise position between its different governmental actors.

Whereas these kinds of internal dynamics can be revealing in terms of the different facets of refugee protection, there is another more tedious dimension to EXCOM sessions that warrants being highlighted because it reflects an important reason why states participate in the collective enterprise known as international refugee protection. Delegations at EXCOM often present from a public relations perspective the positive achievements of their states, while doing their best to appear concerned about refugee problems around the world. Self-promotion, whether by states or organizations, is a key part of the international refugee regime. Indeed, it should not be surprising that states often have an interest in appearing humanitarian while not necessarily committing themselves to significant obligations. Many even present their generosity toward refugees as a defining part of their identity or tradition, regardless of the accuracy of such a representation. This is an understudied, yet fundamental, dimension of the politics of refugee protection. From a cynical perspective, this could mean that an effective delegation is one that is vocal about faraway 
problems while making sure that its own record will not be further scrutinized.

The preceding criticism points to the hypocrisy that sometimes characterizes certain aspects of refugee protection. For example, some EXCOM members may want to adopt international norms or put pressure on other states, while they remain unwilling to discuss their own records. Some members will ask UNHCR to be accountable on a variety of issues such as children or gender, yet they are themselves reluctant to be held accountable to UNHCR.

Much like the dynamic within the former UN Human Rights Commission and the evolving tone of debates within the UN Human Rights Council, the risk of creating a politicized EXCOM is clearly present. Although there are now many new EXCOM members, it is safe to claim that a considerable number of delegations are not particularly active and are represented by lower-level diplomats. Other states, on the other hand, are becoming increasingly bolder and have even begun using the forum to block various collective initiatives. If truth be told, the tendency is such that some states may be suspected of deliberately trying to subvert or sabotage initiatives led by their adversaries. For example, if certain Middle Eastern states do not want birthright registration for handicapped refugees, as members of EXCOM they are legally entitled to advise the High Commissioner on the issue. UNHCR is left with little choice than to retract such seemingly useful initiatives.

\section{Particular Nature of EXCOM Conclusions}

Several observations follow from the state-centred analysis presented in the preceding sections.

In terms of international refugee policy, one concrete outcome of EXCOM sessions is the adoption of so-called conclusions. As EXCOM is not formally mandated to create binding legal rules, the conclusions can be considered a form of soft law. Although the concept of soft law is controversial in general international law circles that consider a norm to be either law or non-law, ${ }^{21}$ human rights advocates tend to use it as an important aspect of the overall normative framework. ${ }^{22}$ Many refugee specialists have already highlighted the contribution of EXCOM conclusions in the progressive development of soft law. ${ }^{23}$

When these non-legal norms are not respected and EXCOM wants to address the problems of implementation, the general approach of member states has been to reaffirm the norms previously endorsed. In particular cases involving important principles, EXCOM may seek endorsement by the UN General Assembly. The intention and hope is that such a procedure will improve the strength of the conclusions and persuade states to respect them. ${ }^{24}$ As we are not dealing with legal norms, there is no formal judicial method to sanction offending states without referring to other binding sources of law.

However, there is a critical way of examining the problem of weak implementation that focuses on lessons learned from a state-centred analysis. While international norm setting is important, it needs to be conducted with caution and prudence because of the voluntary nature of international legal rules that relate to sensitive issues of territorial sovereignty. This critical perspective (at least in relation to orthodox thinking in forced migration studies) suggests that the problems of relativity and double standards have not been sufficiently explored.

Conclusions may contribute to the unhelpful relativity of norms, a problem underappreciated by the many interdisciplinary academics who routinely refer to protection principles without adequate explanation of their nature. ${ }^{25}$ Rather than assuring improved protection, we need to be aware that these discussions carry the risk of reducing the authority of the actual legal obligations imposed on states. To lump a "right to asylum" or "first asylum" principle along with the legally binding prohibition on refoulement can be misleading for those inclined to advocate on behalf of refugees (e.g. encouraging them to exaggerate norms or expect compliance when there is no actual obligation), and as a consequence the approach can suggest to reluctant states that the norms may be generally dismissed as an amalgamation of soft law rules. In other words, such an approach runs the risk of blurring the distinction between binding and non-binding norms.

Let us take the recent Canadian debate on boat people (following the arrival of Tamil asylum seekers on the West Coast) as an example of a potential problem with the conclusion process.

Anyone reading the EXCOM conclusions relevant to the situation of boat people will find out that, according to EXCOM, a potential host state is supposed to accept the asylum seekers on its territory, in an unconditional manner, and regardless of whether they arrive in such large numbers that they may represent a potential security threat. Host states are allowed afterwards to find alternative solutions, but this first step has to be respected in all circumstances according to the EXCOM conclusions that apply to the situation of boat people.

The US and Australia (along with Canada) participated in the consensus decision to adopt the various conclusions that (combined) give us the position outlined above. ${ }^{26}$ These standards were adopted largely in relation to problems confronting coastal states in Asia during the 1970s and 1980s. We also need to keep in mind that American and Australian courts have in recent years applied different standards (i.e. the actual legal norms) in authorizing their states to treat 
boat people in a different manner (i.e. intercepting and sending them elsewhere). ${ }^{27}$ If someone disagrees with the interpretation offered in this section, then it is important to consider that our international system is set up to allow each contracting state to determine the appropriate interpretation of legal obligations by which it is bound. ${ }^{28}$ Unlike other areas of international human rights law, there is no oversight body because states do not want one. In other words, the US Supreme Court's decision allowing the interception and return of Haitian boat people is the final word, at least insofar as international legal obligations are applied in the US.

So why would these influential states adopt soft law norms that directly oppose the actual hard law which their courts apply in practice? As many human rights-related approaches to soft law imply, is it because they want to eventually build up international practice so that the higher norms will actually become the legally binding standards? If so, do we seriously think the US will accept a threatening large-scale movement of boat people onto its shores? Or could it be that these conclusions can be used in a different way, as part of political or diplomatic efforts to persuade less influential states to provide protection in the more remote regions of Africa or Asia? There is an automatic assumption in human rights circles that higher norms are necessarily intended to force us to increase our protection efforts in an egalitarian manner. The idea that we may be deliberately setting double standards seems to escape advocates in the field of forced migration studies. If UNHCR were to have insisted on the EXCOM-established protection policy described above during the recent debate on Tamil boat people arriving in Canada, it would have been ridiculed and marginalized by most mainstream commentators in the country's media.

This brings us to the recent problem at the 60th session, held in 2009, the first year that a protection conclusion was not adopted at the end of the regular session since these instruments have been published.

\section{Historic Failure to Adopt a Conclusion}

For the last few years, the topic of protracted refugee situations (PRS) has become the focus of considerable efforts by UNHCR and its EXCOM. As hinted by the above comments, there is a way of addressing the problem of PRS in a less upbeat way than has been presented by analysts working alongside the Canadian government in order to ensure PRS is on the international agenda. ${ }^{29}$

A considerable amount of political effort was invested in the PRS campaign, including a two-day "protection dialogue" organized by the High Commissioner in December 2008. It is noteworthy that a rich member state such as
Canada, which is not directly confronted with the PRS problem (and which receives only a tiny fraction of the world's many refugees), would play a leadership role on this problem with the intention of guiding EXCOM towards the adoption of a conclusion detailing the applicable norms.

A critical interpretation of what has been achieved in terms of PRS at EXCOM might suggest that the topic contributed in blocking the conclusion process and in aggravating the growing tensions between delegations already divided along North-South lines. After all, the 60th session was the first time that no protection conclusions were adopted during a regular annual session. ${ }^{30}$ Was the "compromise" text finally adopted in an extraordinary session held two months later worth it? ${ }^{31}$ Was it really a step forward when considered along with the problems it created?

From the perspective of poorer refugee-hosting states, it is possible that their representatives are fed up with rich northern states pontificating about the importance of protection ... while avoiding contact with refugees thanks to their geographic position and their interdiction policies. It is difficult to ignore that Canada was pushing for norms to be adopted by EXCOM, while many poorer refugee-hosting states were sceptical for a variety of reasons. If Canada wanted to show credibility on this issue which directly affects other states, genuine leadership would suggest that it should have committed itself by providing the poorer host states with financial help. ${ }^{32}$ In other words, a commitment to share the burden (and not simply provide discretionary aid) is arguably the only credible involvement on this issue.

Promises of (limited and discretionary) so-called "strategic" resettlement are not enough, particularly when it is relatively clear that it forms part of larger Western attempts to persuade the poorer southern states to ultimately accept local integration as the actual durable solution for warehoused refugees. For the optimists inclined to believe that massive repatriation will resolve PRS, the historical record suggests we should be a little more pessimistic. Indeed, as relatively few refugees in protracted situations will be resettled and as it is unlikely that many countries of origin will become safe for return, it would not be surprising if poorer states realize that behind the rhetoric may lie an attempt to prepare the terrain for the actual solution favoured by rich states: local integration in the faraway poor countries. ${ }^{33}$

Therefore poorer refugee-hosting states have reasons to oppose seemingly well-intentioned humanitarian initiatives from rich states like Canada. It is not astonishing that a state which has hosted many refugees for prolonged periods such as Iran, which also receives limited international aid and which has difficult diplomatic relations with Canada, would not co-operate in EXCOM deliberations on PRS partly led by the Canadian delegation. Indeed, the suggestion by the 
Canadian delegation that "[m]illions of refugees are counting on us to secure a positive outcome" 34 in terms of adopting a conclusion on PRS is not only an exaggeration of the effects of these soft law instruments, it may also appear as unsophisticated diplomatic pressuring to some observers.

A critical approach to forced migration studies does not simply limit itself to advocating for higher protection norms and blaming governments for not implementing these norms. The public relations dimension of humanitarian action should suggest that some initiatives may actually conceal other concerns that are not about equitable burden-sharing.

If we really want to advance North-South co-operation and introduce some equity in the global distribution of refugees (and the accompanying burdens on host states), then it is more useful to tackle the burden-sharing problem in a direct manner. However, past experiences in EXCOM suggest that the enthusiasm of rich states disappears when the discussion turns to burden-sharing which entails the possibility of assuming actual obligations despite geographical distance.

A blunt and upfront analysis has its benefits, at least in terms of thinking about constructive efforts that allow us to focus on genuine solutions. After all, solutions are going to be institutional. Unless one believes that the refugee specialists can do everything, it makes little sense to have UNHCR also focus on lots of different activities which do not relate directly to asylum (e.g. resolving the problems that make people flee in the first place). ${ }^{35}$ In this sense, it is not clear that the concern about PRS advocacy is fundamentally different from the old "root causes" concern of a couple of decades ago. ${ }^{36}$ There is a danger that the refugee specialists are being sidetracked from core issues and led towards optimistic promises about peace building and post-conflict reconstruction:

[T]he Convention Plus initiative lost itself in highly specific issues, most likely on account of the Agenda for Protection, with its emphasis on the need to solve protracted refugee situations, without explanation as to how those specifics would contribute to an effective system of global burden-sharing (the focus on specific refugee situations could not be expected to yield the requisite fundamental analysis or substitute for such analysis either). ${ }^{37}$

If UNHCR were doing really well in relation to its core responsibilities, the interest in such expansion could be understandable. But that is not the dynamic at work here. ${ }^{38}$ In the meantime, UNHCR is arguably somewhat absent in terms of contributing to the boat people issue, the one problem that was directly affecting Canada during the period preceding and following the 60th session, not to mention an issue that affects Australia and the influential EU states from the Mediterranean region.

The above analysis may explain some of the new tensions and dynamics within EXCOM. Is there a crisis in norm making? Perhaps. Yet the problem is not necessarily the one being highlighted by many advocates. In any case, it is revealing that UNHCR is increasingly being excluded from the state-led negotiations relating to the EXCOM session.

The above comments on PRS are related to previous concerns raised about mandates. As non-Western voices gain prominence in EXCOM, UNHCR will have more difficulty in defending itself against a basic critique of the recent evolution of the refugee protection system:

What we are seeing today is the revival of the liberal culturalpolitical ideas of progress and reform that informed the colonial project ... Political humanitarianism has refused to be limited by the classic concept of humanitarianism with its emphasis on the principles of impartiality, neutrality and independence. In the post-cold-war era international humanitarian agencies, both governmental and non-governmental, have come to accept the view that it is their task to address both the causes and the aftermath of a humanitarian crisis ... One result is that humanitarian agencies have begun to neglect local voices as these often conflict with the agenda of states that fund them ... Much of the changed approach can be traced to the desire of humanitarian agencies to be active participants in transforming the non-western world in ways that realize the Western vision of good governance. ${ }^{39}$

\section{Conclusion}

While there may be several explanations for the failure to adopt a protection conclusion during the regular 60th session, this commentary urges analysts to focus on the lessons that may be learned from a legal positivist reading of international obligations and mandates.

Many analysts have already noted that UNHCR's mandate sometimes appears to be losing clarity, yet one basic aspect on which we need to agree is that this historic institution was never intended to be (and cannot be expected to act as) a strong advocacy watchdog-type body. There are clearly limits to how much states will allow themselves to be led by the legal services of a multilateral institution (i.e. UNHCR's Division of International Protection) in the implementation of important norms concerning refugees that seek access to their territories.

These comments point to the observation that there are diverging views on the relative independence of UNHCR and how this affects EXCOM. There are similar divergences on the future of the EXCOM conclusion process. Should the focus now be to fix the process or to drop it while pushing 
elsewhere for the development of norms? The wider UN system, for example, allows for possibilities to advance various (soft law) norms in other settings such as in the human rights committees. These choices reflect underlying tensions within EXCOM that relate to different protection approaches which can be roughly categorized by their emphasis on consensusbuilding or on progressive advocacy.

As a body created by UN member states and supported by different governments with varying political/cultural traditions (including non-liberal ones), UNHCR's mandate should be interpreted with moderation and a reasonable (yet critical) respect for state sovereignty. One of the consequences of an increasingly democratic forum such as EXCOM is that a variety of perspectives and issues will be raised by member states. This is a fact of life in international organizations that want to truly represent their diverse constituents and we have to live with the limitations of action which may result. While donor funding trends do not indicate for the moment any major changes, EXCOM may be shifting slightly away from the Western-controlled forum that has existed since the 1950s. If we believe in the sovereign equality of states, and lack a viable alternative that can address inequality, ${ }^{40}$ this development should not necessarily be seen in a negative light by those who oppose a hegemonic liberal project that seeks to reshape international policy making on forced migration issues.

Likewise, if we accept that primary responsibility for refugee protection lies with states, then the flip side of this proposition is that states have a key role in determining the norms. If they prefer to politicize protection debates in EXCOM and not to recommend effective approaches, then there is no magic way of bypassing this impasse. When we consider the risks of politicization, we should also appreciate that it can take many forms. For behind the more direct forms that involve open accusations, there have always been the more subtle forms that involve scoring public relations points and maintaining a humanitarian façade. Genuine leadership will move beyond these diversions and recognize the human plight that demands we assume responsibility for our collective worldwide protection failures.

\section{Notes}

1. "Les représentants ... seront nommés par le Haut Commissaire de la Société des Nations, avec l'agrément des gouvernements intéressés. Ils exercent leurs attributions dans les conditions arrêtées d'un commun accord entre les gouvernements intéressés et le Haut Commissaire." Accord relatif au fonctionnement des services du Haut Commissaire de la Société des Nations pour les réfugiés, Recueil des Traités de la Société des Nations, no. 2126, vol. 93, 1929, p. 378 (signed in Geneva on 20 June 1928).
2. "Pressures on UNHCR would appear to be increasing, with governments openly critical of it for taking on an advocacy cum prosecuting judge role, rather than assisting states to cope with the changed refugee context." Adrienne Millbank, The Problem with the 1951 Refugee Convention, Research Paper no. 5, Parliamentary Library of Australia, 5 September 2000, 19.

3. Anthony M. North and Joyce Chia, "Towards Convergence in the Interpretation of the Refugee Convention: A Proposal for the Establishment of an International Judicial Commission for Refugees," Australian Year Book of International Law, vol. 25 (2006), 261.

4. Volker Turk, "UNHCR's Role in Supervising International Protection Standards in the Context of Its Mandate" (keynote address, International Conference on Forced Displacement, Protection Standards, Supervision of the 1951 Convention and the 1967 Protocol and Other Internationa Instruments, York University, Toronto, 19 May 2010), 15.

5. Erika Feller, "Protecting People in Conflict and CrisisResponding to the Challenges of a Changing World" (keynote address, Protecting People in Conflict and Crisis: Responding to the Challenges of a Changing World, Refugee Studies Centre, University of Oxford, 22 September 2009), 1-2.

6. K.R.S. v. United Kingdom, Application no. 32733/08, Council of Europe: European Court of Human Rights, 16, 2 December 2008.

7. “The High Commissioner's Office for Refugees should (a) be so organized within the framework of the United Nations as to possess the degree of independence and the prestige required for the effective performance of the High Commissioner's duties." UNGA, Resolution 319 (IV), (3 December 1949), para. 1 (a).

8. See, e.g., Rapport du Secrétaire général sur les réfugiés, doc. A.28.1930.XIII, 30 (August 1930); and Rapport présenté à l'Assemblée par le sixième comité (rapporteur M. FrançoisPoncet, France), doc. A.75.1930.XIII (27 September 1930).

9. See UNGA Resolution 1166 (XII), 26 November 1957, para. 5 (b).

10. Jerzy Sztucki, "The Conclusions on the International Protection of Refugees Adopted by the Executive Committee of the UNHCR Programme," International Journal of Refugee Law 1, no. 3 (1989): 203.

11. Ibid.

12. The uniqueness of this situation has been noted in ibid., 294: "Yet, in contradistinction to most, if not all, organs of the United Nations, draft conclusions are not submitted by the participating delegations, but by the Office of the UNHCR, as final sections of the respective Notes elaborated within the Division of Refugee Law and Doctrine for every substantive item on the Sub-Committee agenda. Also, the agenda itself is drawn-up by UNHCR, although Members of the Executive Committee keep asking for an input." 
13. In terms of recent insights in the political theory of international relations, this commentary suggests that examination of pathological organizational behaviour is not limited to analyses that avoid a state-centric focus. See Michael N. Barnett and Martha Finnemore, "The Politics, Power, and Pathologies of International Organizations," International Organization 53, no. 4 (1999): 715.

14. For a critical analysis by the head of the French delegation at the Conference, see François Leduc, "Lasile territorial-Conférence des Nations Unies," Annuaire français de droit international 23 (1977), 256: "Les choses étant ce quelles sont, la déception sera vive au Haut Commissariat des Nations Unies pour les réfugiés qui a été l'initiateur de cette Conférence, y a travaillé pendant des années et a dû constater son insuffisante préparation et une évaluation inexacte des différents courants de pensée. Tout aussi vive sera la déception des organisations non gouvernementales, très attachées à ce projet, qui ont commis la même erreur d'appréciation que le HCR ainsi que celle des pays ayant une tradition libérale de l'octroi du droit d'asile."

15. Sztucki, "The Conclusions on the International Protection of Refugees Adopted by the Executive Committee of the UNHCR Programme," 297.

16. Ibid., 311.

17. See, e.g., the report commissioned by UNHCR's Policy and Evaluation Services on border closures that addresses the tensions between principles and operational realities, while presenting the analysis on the basis of a supposed "obligation to offer asylum." Kate Long, No entry! A review of UNHCR's response to border closures in situations of mass refugee influx, UNHCR/PDES, June 2010, 2.

18. Marjoleine Zeick, "Doomed to Fail from the Outset? UNHCR's Convention Plus Initiative Revisited," International Journal of Refugee Law 21, no. 3 (2009): 387-420, at 413.

19. See Atle Grahl-Madsen, Territorial Asylum (New York: Oceana Publications, 1980), 61-80.

20. The Canadian delegation, for example, generally shows up with representatives from Citizenship Immigration Canada, the Department of Foreign Affairs and International Trade, Canada Border Services Agency, and the Canadian International Development Agency.

21. See, e.g., Martin Dixon, Textbook on International Law, 6th ed. (Oxford: Oxford University Press, 2007), 50, in which this use of the term is considered as unhelpful in that it is "not really law at all."

22. Dinah Shelton, "International Law and Relative Normativity" in Malcolm D. Evans, ed., International Law, 2nd ed. (Oxford: Oxford University Press, 2006), 182: "Despite their limited juridical effect, non-binding instruments have an essential and growing role in international relations and in the development of international law."

23. See, e.g., Sztucki, "The Conclusions on the International Protection of Refugees Adopted by the Executive Committee of the UNHCR Programme," 307: "Denying their normative character from the juridical point of view is not to deny their normative function at all ... the term 'soft law' is a handy formula, denoting a body of non-legal and nonbinding provisions, still having normative purport and, possibly, also some legal relevance." See also Bryan Deschamps and Rebecca Dowd, "Review of the Use of UNHCR Executive Committee Conclusions on International Protection," report for UNHCR's Policy Development and Evaluation Service, April 2008, 5.

24. Sztucki, "The Conclusions on the International Protection of Refugees Adopted by the Executive Committee of the UNHCR Programme," 312-16.

25. See, e.g., Alexander Betts and Jean-François Durieux, "Convention Plus as a Norm-Setting Exercise," Journal of Refugee Studies 20, no. 3 (2007), 510: "Asylum implies that states have obligations towards refugees who reach their territory ... the principle of asylum is supported by a relatively strong legal sub-regime."

26. See EXCOM conclusions no. 22 (1981), 23 (1981), 85 (1998), and 100 (2004).

27. See Sale v Haitian Centers Council, 113 S CT 2549 (1993) and Ruddock $v$ Vadarlis [2001] FCA 1329.

28. James C. Hathaway, "A Reconsideration of the Underlying Premise of Refugee Law," Harvard International Law Journal 31, no. 1 (1990), 166: "[A] dominant feature of modern refugee law is its establishment of a protection system over which individual states, rather than an international authority, have effective control."

29. See, e.g., Adèle Dion, "Protracted Displacement: Comprehensive Solutions-A Whole-of-Government Approach," Forced Migration Review 33 (September 2009): 28-29; Gil Loescher and James Milner, "Protracted Displacement: Understanding the Challenge," Forced Migration Review 33 (September 2009): 9-11.

30. Protection Statement of the Government of Canada to the 60th Session of EXCOM, 30 September 2009, p. 1: "We have strongly supported the work of the High Commissioner and the UNHCR to focus on protracted refugee situations over this past year. We were especially impressed by the partnerships, particularly with development agencies and peace and security actors that have been undertaken to better respond to protracted contexts ... We note with disappointment that Member States were unable to secure a consensus on the Conclusion on Protracted Refugee Situations in time for this meeting."

31. EXCOM conclusion no. 109 (2009).

32. Statement by Hon. Lawrence K. Masha, Minister for Home Affairs, United Republic of Tanzania, at the 60th Session of EXCOM, 29 September 2009, 7: "As the global crisis and economic downturn deepens, taking its toll on the economics of most nations, it is the underdeveloped and the poor nations which are mostly affected. Yet these are the countries that carry the biggest burden of hosting hundreds of thousands of refugees."

33. Statement by H. E. Mr. Taghi Ghaemi, Bureau for Aliens and Foreign Immigrants Affairs, Ministry of the Interior of 
the Islamic Republic of Iran, at the 60th Session of EXCOM, 29 September 2009, 3-4: "Suggesting local integration as a solution provides crisis for the host countries especially in the mass influx situations could not be accepted. We therefore expect that the international community would refrain from providing unrealistic and irrational remedies."

34. Protection Statement of the Government of Canada to the 60th Session of EXCOM, 30 September 2009, 2: "We urge all countries to continue to negotiate the text in the coming months to ensure that it can be adopted as soon as possible. Millions of refugees are counting on us to secure a positive outcome."

35. Statement by H. E. Ambassador Reinhard Schweppe, Permanent Representative of the Federal Republic of Germany to the UN, at the 60th Session of EXCOM, 28 September 2009, 4: "[T] UNHCR to do the whole job on its own."

36. See the critique in James C. Hathaway, "Why Refugee Law Still Matters," Melbourne Journal of International Law 8, no. 1 (2007), 98. .
37. Zeick, "Doomed to Fail from the Outset?" 419.

38. On the serious problems of access to asylum, as well as allegations of refoulement and naval "push backs" in the Mediterranean region, see NGO Statement on Agenda Item 4 (General Debate) at the 60th Session of EXCOM, 29 September 2009, 3.

39. B. S. Chimni, “The Birth of a 'Discipline': From Refugee to Forced Migration Studies," Journal of Refugee Studies 22, no. 1 (2009): 20-22.

40. Benedict Kingsbury, "Sovereignty and Inequality," European Journal of International Law 9 (1998): 616.

Michael Barutciski is editor-in-chief of Refuge and graduate program director at the Glendon School of Public and International Affairs, York University, Toronto. The research for this commentary was made possible by a SSHRC grant. 